\title{
Growth hormone therapy and risk of recurrence/progression in intracranial tumors: a meta-analysis
}

\author{
Liang Shen ${ }^{1}$ Chun Ming $\mathrm{Sun}^{2} \cdot$ Xue Tao $\mathrm{Li}^{2} \cdot$ Chuan Jin $\mathrm{Liu}^{2} \cdot$ You Xin Zhou
}

Received: 28 November 2014/ Accepted: 27 May 2015/Published online: 6 June 2015

(c) The Author(s) 2015. This article is published with open access at Springerlink.com

\begin{abstract}
Growth hormone deficiency is common in intracranial tumors, which is usually treated with surgery and radiotherapy. A number of previous studies have investigated the relationship between the growth hormone replacement therapy (GHRT) and risk of tumor recurrence/ progression; however, the evidence remains controversial. We conducted a meta-analysis of published studies to estimate the potential relation between GHRT and intracranial tumors recurrence/progression. Three comprehensive databases, PUBMED, EMBASE, and Cochrane Library, were researched with no limitations, covering all published studies till the end of July, 2014. Reference lists from identified studies were also screened for additional database. The summary relative risks (RR) and $95 \%$ confidence intervals (CI) were calculated by fixed-effects models for estimation. Fifteen eligible studies, involving more than 2232 cases and 3606 controls, were included in our meta-analysis. The results indicated that intracranial tumors recurrence/progression was not associated with GHRT (RR 0.48, $95 \%$ CI 0.39-0.56), and for children, the pooled RR was 0.44 and $95 \%$ CI was $0.34-0.54$. In subgroup analysis, risks of recurrence/progression were decreased for craniopharyngioma, medulloblastoma, astrocytoma, glioma, but not for pituitary adenomas, and non-functioning pituitary adenoma (NFPA), ependymoma.
\end{abstract}

L. Shen and C. M. Sun contributed equally to this work.

You Xin Zhou

20125232086@suda.edu.cn

1 Department of Neurosurgery, Huzhou Central Hospital, Huzhou 313100, Zhejiang, China

2 Brain and Nerve Research Laboratory, Department of Neurosurgery, The First Affiliated Hospital of Soochow University, 188 Shizi Road, Suzhou 215006, Jiangsu, China
Results from our analysis indicate that GHRT decreases the risk of recurrence/progression in children with intracranial tumors, craniopharyngioma, medulloblastoma, astrocytoma, or glioma. However, GHRT for pituitary adenomas, NFPA, and ependymoma was not associated with the recurrence/progression of the tumors. GH replacement seems safe from the aspect of risk of tumor progression.

Keywords Intracranial tumors - Growth hormone - Risk · Recurrence $\cdot$ Meta-analysis

\section{Introduction}

Surgical resection, radiotherapy, and chemotherapy are currently some of the most efficient treatment methods for brain tumors [1]. However, complications resulting from the management of the tumor are serious, such as growth hormone deficiency (GHD). GHD is often found in tumors post-irradiation or tumors related to sella turcica, such as pituitary adenomas and craniopharyngioma. Growth hormone $(\mathrm{GH})$ plays a significant role in metabolism. It regulated fuel homeostasis and promotes growth through glycometabolism, lipid metabolism, and protein anabolism [2]. Thus, continued exogenous GH infusion is considered in GHD patients, especially those having a disorder of metabolism or a low quality of life.

The safety of GHRT in tumor management remains controversial. Three hundred sixty one children, enrolled in the Childhood Cancer Survivor Study, were treated with $\mathrm{GH}$. The rate ratio of GHRT survivors developing a second neoplasm, as compared to no-GHRT survivors, was 2.15 (95\% CI 1.3-3.5) [3]. Furthermore, in patients with prolonged critical illness, high doses of GH are associated with increased morbidity and mortality [4]. However, recent 
studies have demonstrated that long-term GH use in hypopituitarism may be considered safe in patients with central nervous system (CNS) tumors [5-7]. However, the role of GHRT toward the progression of CNS tumor in patients remained poorly understood. Therefore, we conducted a meta-analysis of published observational studies to validate the role of $\mathrm{GH}$ in intracranial tumors.

\section{Materials and methods}

\section{Research strategy}

Reviewers (LS and CMS) performed a systematic literature search independently from three databases, PUBMED, EMBASE, and Cochrane Library for published studies without limitations. Reviewers used the following terms as research strategy: ([MeSH] "brain neoplasms" or "intracranial tumors" or "seller tumors" or "brain tumors") and $([\mathrm{MeSH}]$ "growth hormone" or "growth hormone deficiency*" or "growth hormone replacement therapy" or "GH replacement therapy" or "GHRT"), and ([MeSH] "recurrence" or "recurrence" or "progression" or "enlargement"). No limitations were imposed. A manual search of identified articles' references was performed for additional studies.

\section{Study selection}

The studies were selected using the following criteria: (1) case-control study or cohort design; (2) intracranial tumors treated with growth hormone; (3) relationship between GHRT and recurrence/progression of intracranial tumors was assessed; (4) values of RRs and the corresponding $95 \%$ CIs or sufficient data were estimated; and (5) study with largest sample size or the most recent study in metaanalysis if the same study population was published several times was chosen.

\section{Data extraction and methodological assessment}

The following data were independently extracted from of the participants involved in the study: surname of the first reviewer, publication year and country of literature, age at diagnosis of subjects in the study, numbers of case and control groups, follow-up and GH therapy years, methods of recurrence/progression diagnosis, and study quality. Methodological quality was evaluated standardly by two observers using the Newcastle-Ottawa Scale (NOS) criteria [8]. NOS included three steps: (1) subject selection, 0-4; (2) comparability of subject, $0-2$; and (3) clinical outcome, $0-3$. The NOS scores ranged from zero to nine. A score of six or more indicated a good quality; otherwise, the study is deemed to have relatively lower quality. All the disagreements were resolved carefully by two reviewers through discussion.

\section{Statistical analysis}

The STATA software (Version 12.0, Stata Corporation, College Station, TX, USA) was used for the analysis. RR values and the corresponding $95 \% \mathrm{CI}$ were used to estimate the relationship between GHRT and risk of recurrence/ progression in intracranial tumors with GHD. Heterogeneity, in the analysis, was evaluated by the $\mathrm{Q}$ statistic and $I^{2}$ statistic $[9,10]$. Heterogeneity was tentatively assigned with the values corresponding to middle heterogeneity and notable heterogeneity: $I^{2}$ values $<30$ and $>50 \%$ [9]. $p>0.1$ for the Q statistic or $I^{2}<50 \%$ for the $I^{2}$ statistic were considered statistically insignificant [10]. If heterogeneity was indicated, random-effect model was used; otherwise, fixed-effect model was employed [11]. Moreover, subgroup analyses were performed to explore potential factors for heterogeneity. In order to assess the stability of each study for the overall estimation, sensitivity and publication bias analyses were conducted as described previously [11]. For the best possible information available, more than one method for bias was conducted for assessment, for example Egger's test and Begg's funnel plot [12, 13]. Briefly, sensitivity analysis was employed to assess the impact of individual study on the overall estimation.

\section{Results}

\section{Literature search and study characteristics}

Figure 1 summarizes the flow chart of literature search and selection. A total of 524 articles were selected for identification. Fifteen studies, published from 1985 to 2013, were selected in the meta-analysis. Of the 15 studies, six were carried out from UK, three from USA, two from Germany, two from Sweden, one from Norway, and one from Canada. Additional characteristics of the included studies are shown in Table 1. As shown in table, seven of the selected studies obtained seven or more scores, which indicated that the study quality was relatively higher [5-7, 14-22]; whereas, other studies with relatively lesser scores were considered of lower quality [23-25].

\section{Correlation of GHRT- and GH-deficient intracranial tumors}

Different types of GH-deficient intracranial tumors were researched in the studies. As shown in forest plots, the pooled RR for GHRT versus no-GHRT was 0.48 (95\% CI 
Fig. 1 Flow chart of literature selection

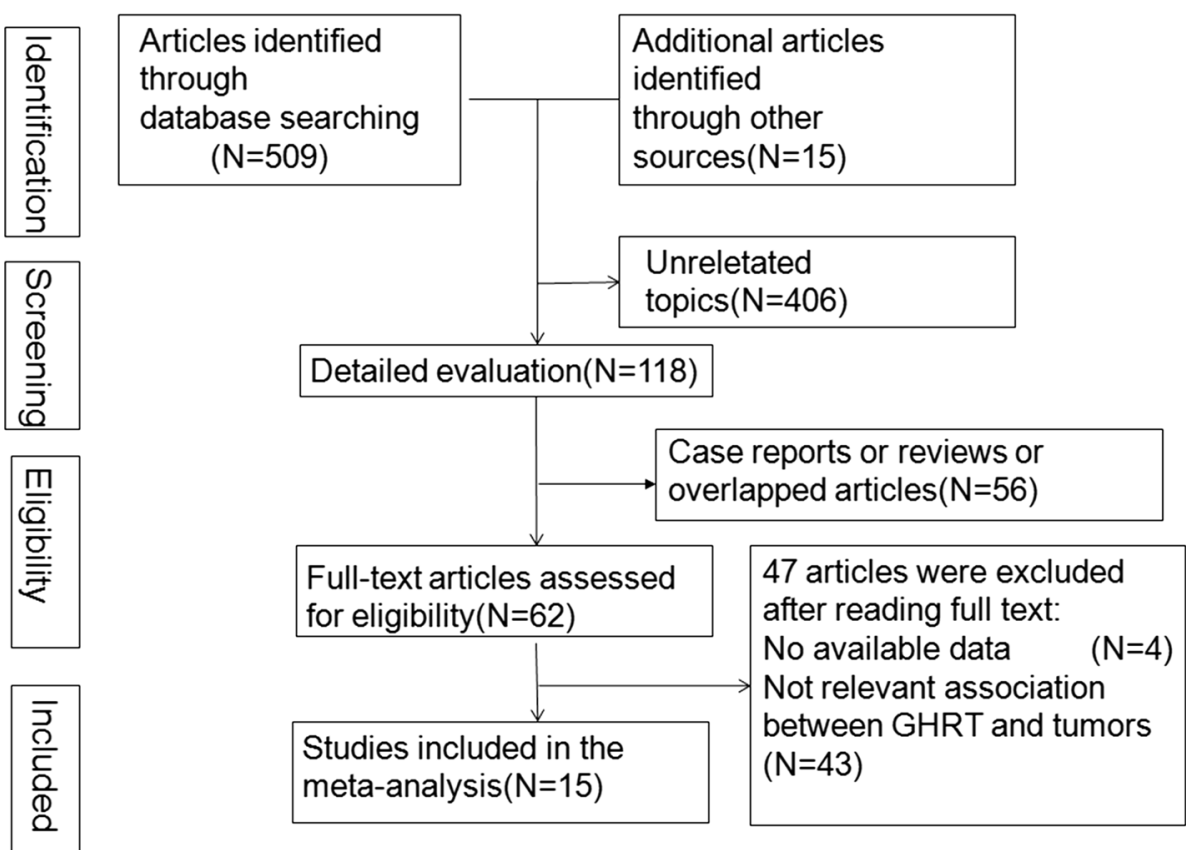

GHRT for brain tumors

As shown in Fig. 5, the combined RR for medulloblastoma was 0.27 (95\% CI $0.17-0.42 ; I^{2}=3.7 \%, p$ for heterogeneity $=0.374)$. RRs for ependymoma and astrocytoma were 0.87 (95\% CI $0.52-1.47 ; I^{2}=0.0 \%, p$ for heterogeneity $=0.536)$ and $0.51 \quad(95 \%$ CI $0.29-0.93$; $I^{2}=0.0 \%, p$ for heterogeneity $\left.=0.675\right)$, respectively. Ependymoma and astrocytoma were part of glioma, and the pooled RR for glioma was 0.64 (95\% CI $0.45-0.90$; $I^{2}=22.8 \%, p$ for heterogeneity $=0.274$ ).

\section{Sensitivity analysis and publication bias}

For sensitivity analysis, we left out each of the studies, in turn, to investigate the influence of a single study on the overall risk estimation. In Fig. 6, the corresponding RRs for GHRT versus no-GHRT were not significantly altered. The Begg's funnel plot showed that the RR values were symmetrical. The results from the Egger's test suggested that there was no pronounced publication bias ( $p$ for Egger's test of all types of intracranial tumors, and tumors in children were 0.453 and 0.121 , respectively).

\section{Discussion}

While hypothalamus and pituitary axis were blocked or broken because of tumor, surgical resection, radiotherapy, and GHD occurred with serious clinical symptoms, such as increased morbidity. GH was injected to balance the endocrine system. However, infused GH raised the serum 
Table 1 Characteristics of studies included in the meta-analysis

\begin{tabular}{|c|c|c|c|c|c|c|c|}
\hline References & Ages (years) & Cases/controls & $\begin{array}{l}\text { Follow-up } \\
\text { period } \\
\text { (years) }\end{array}$ & $\begin{array}{l}\text { GH therapy } \\
\text { period (years) }\end{array}$ & $\begin{array}{l}\text { Recurrence/ } \\
\text { progress } \\
\text { diagnosis }\end{array}$ & Intracranial tumor types & $\begin{array}{l}\text { Study } \\
\text { quality }\end{array}$ \\
\hline $\begin{array}{l}\text { Arslanian et al. } \\
\text { [23], USA }\end{array}$ & NR (C) & $8 / 24$ & 5.5 & NR & $\mathrm{CT}$ & $\begin{array}{l}\text { Craniopharyngioma, } \\
\text { germinoma, } \\
\text { medulloblastoma, glioma, } \\
\text { dermoid, retinoblastoma, } \\
\text { metastatic } \\
\text { rhabdomyosarcoma, } \\
\text { chromophobe adenomas }\end{array}$ & 6 \\
\hline $\begin{array}{l}\text { Clayton et al. } \\
\text { [24], Norway }\end{array}$ & $10.8 \pm 2.2$ & $13 / 21$ & NR & NR & NR & Medulloblastoma, glioma & 6 \\
\hline $\begin{array}{l}\text { Ogilvy-Stuart } \\
\text { et al. [25], UK }\end{array}$ & $<14.4$ & $47 / 160$ & 5.1 & NR & NR & Medulloblastoma, glioma & 6 \\
\hline $\begin{array}{l}\text { Swerdlow et al. } \\
\text { [14], UK }\end{array}$ & $<16$ & $179 / 910$ & $\begin{array}{l}6.4^{\mathrm{a}} \\
4.5^{\mathrm{b}}\end{array}$ & NR & NR & $\begin{array}{l}\text { Medulloblastoma, glioma, } \\
\text { others }\end{array}$ & 8 \\
\hline $\begin{array}{l}\text { Packer et al. [15], } \\
\text { Canada }\end{array}$ & $<15$ & 545 & 5 & NR & NR & Medulloblastoma & 7 \\
\hline $\begin{array}{l}\text { Sklar et al. [16], } \\
\text { USA }\end{array}$ & $<17.2$ & $172 / 1489$ & 6.2 & 4.6 & NR & Medulloblastoma, glioma & 8 \\
\hline $\begin{array}{l}\text { Hatrick et al. } \\
\text { [17], UK }\end{array}$ & NR & $47 / 28$ & NR & 3.4 & CT MRI & $\begin{array}{l}\text { Pituitary tumors, } \\
\text { craniopharyngioma, } \\
\text { meningioma }\end{array}$ & 7 \\
\hline $\begin{array}{l}\text { Karavitaki et al. } \\
\text { [18], UK }\end{array}$ & $\begin{array}{l}17.6 \pm 14.3^{\mathrm{a}} \\
38.8 \pm 16.8^{\mathrm{b}}\end{array}$ & $32 / 53$ & $\begin{array}{l}10.8 \pm 9.2^{\mathrm{a}} \\
8.3 \pm 8.8^{\mathrm{b}}\end{array}$ & $6.3 \pm 4.6$ & CT MRI & Craniopharyngioma & 8 \\
\hline $\begin{array}{c}\text { Buchfelder et al. } \\
\text { [19], Germany }\end{array}$ & NR & $55 / 55$ & 5 & $8.2 \pm 6.7$ & MRI & Pituitary adenomas & 8 \\
\hline $\begin{array}{l}\text { Olsson et al. [20], } \\
\text { Sweden }\end{array}$ & $\begin{array}{l}49.6 \pm 12.8^{\mathrm{a}} \\
51.6 \pm 12.0^{\mathrm{b}}\end{array}$ & $121 / 114$ & $\begin{array}{l}9.9 \pm 3.9 \\
10.1 \pm 4.4\end{array}$ & $10 \pm 4$ & CT MRI & Pituitary adenomas & 7 \\
\hline $\begin{array}{l}\text { Arnold et al. [5], } \\
\text { UK }\end{array}$ & $\begin{array}{l}53.7 \pm 14.6^{\mathrm{a}} \\
56.2 \pm 14.0^{\mathrm{b}}\end{array}$ & $23 / 107$ & $6.8 \pm 4.2$ & $4.6 \pm 2.5$ & CT MRI & Pituitary adenomas & 7 \\
\hline $\begin{array}{l}\text { Rohrer et al. } \\
\text { [21], Germany }\end{array}$ & $<17.5$ & $44 / 59$ & $\begin{array}{l}7.5^{\mathrm{a}} \\
4.5^{\mathrm{b}}\end{array}$ & NR & NR & $\begin{array}{l}\text { Craniopharyngioma, } \\
\text { medulloblastoma, } \\
\text { ependymoma }\end{array}$ & 8 \\
\hline $\begin{array}{l}\text { Mackenzie et al. } \\
\text { [6], UK }\end{array}$ & $\begin{array}{l}33^{\mathrm{a}} \\
29^{\mathrm{b}}\end{array}$ & $110 / 110$ & $\begin{array}{l}14.5^{\mathrm{a}} \\
15^{\mathrm{b}}\end{array}$ & $\begin{array}{l}8^{\mathrm{a}} \\
\mathrm{NR}^{\mathrm{b}}\end{array}$ & CT MRI & $\begin{array}{l}\text { Pituitary adenomas, } \\
\text { craniopharyngioma, } \\
\text { intracranial neoplasm }\end{array}$ & 7 \\
\hline $\begin{array}{l}\text { Olsson et al. [7], } \\
\text { Sweden }\end{array}$ & $\begin{array}{l}25.1 \pm 16.4^{\mathrm{a}} \\
32.3 \pm 16.9^{\mathrm{b}}\end{array}$ & $56 / 70$ & $\begin{array}{l}13.6 \pm 5.0^{\mathrm{a}} \\
13.4 \pm 7.8^{\mathrm{b}}\end{array}$ & $13.6 \pm 5.0$ & CT MRI & Craniopharyngioma & 7 \\
\hline $\begin{array}{l}\text { Hartman et al. } \\
\text { [22], USA }\end{array}$ & NR & $1309 / 339$ & $\begin{array}{l}2.3 \pm 1.4^{\mathrm{a}} \\
2.3 \pm 1.6^{\mathrm{b}}\end{array}$ & $0.5-1$ & NR & $\begin{array}{l}\text { Pituitary adenomas, } \\
\text { craniopharyngioma. others }\end{array}$ & 6 \\
\hline
\end{tabular}

$C T$ computed tomography, $F$ female, $M R I$ magnetic resonance imaging, $M$ male, $N R$ not reported

${ }^{\text {a }}$ Case group

b Control group

concentration of insulin-like growth factors-1 (IGF-1), which stimulated cell proliferation and inhibited apoptosis [27].

In the analysis of association between GHRT and GHdeficient intracranial tumors, results have indicated that GHRT was correlated with a decrease risk of tumor recurrence/progression. In the subgroup analyses, decreased risks were also obtained from craniopharyngioma, medulloblastoma, astrocytoma, and glioma. Irrelevant risks of tumor recurrence/progression were acquired from pituitary adenomas, NFPA, and ependymoma. However, the fluctuation in serum levels of GH and IGF-1 was observed in neoplastic disease, which might affect tumor progression [28]. In addition, Renehan et al. conducted a 


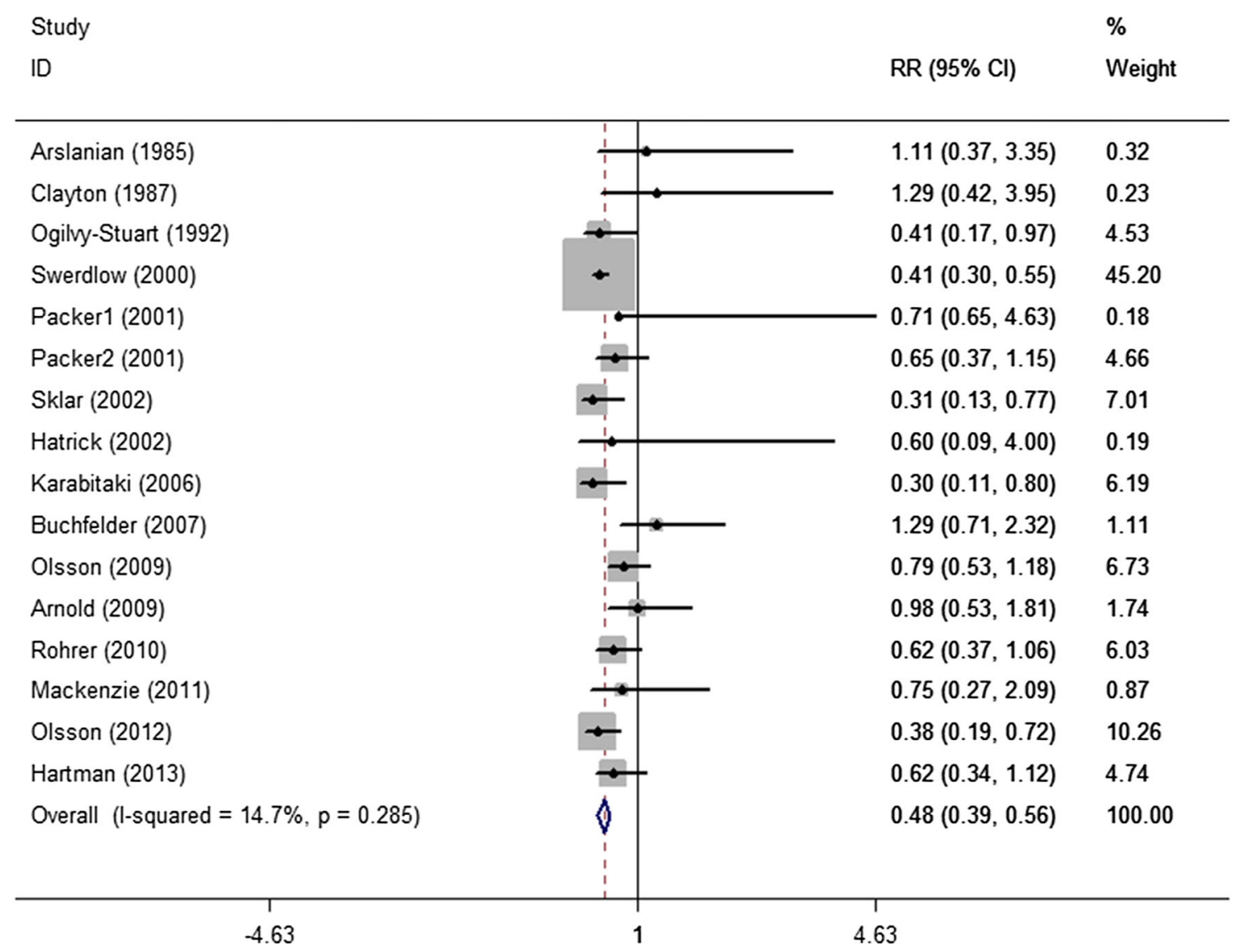

Fig. 2 Forest plot of GHRT and tumor recurrence/progression in GH-deficient intracranial tumors

meta-regression analysis and demonstrated that high level of IGF-1 contributed to carcinogenesis in prostate, colorectal, and premenopausal breast cancers [29]. However, the results from intracranial tumors treated with GH indicated that GHRT was not associated with increased risk of recurrence/progression. During the period of GH treatment, the dose of GH was adjusted regularly depending on serum level of IGF-1 [5]. Thus, in patients treated with GH, the level of GH was elevated in accordance with the normal reference levels of IGF-1. Berg et al. confirmed that IGF-1 levels were influenced by several factors other than GH [30]. GH was found to induce high levels of IGF-1 in many malignancies [31, 32]. In our meta-analysis, most of tumors were benign. Renehan et al. also demonstrated that highnormal levels of IGF-1 had no influence on postmenopausal and lung cancer [29]. From this inconformity, $\mathrm{GH}$ might promote the progression of some of the tumors, but not all. It was undeniable that heterogeneity resulted in varied effects of tumors on same interventions.

More detailed information on age, which was major risk factor for tumors, was taken into consideration. Results have confirmed that GHRT in children decreased the risk of tumor recurrence/progression (RR $0.44,95 \%$ CI
0.34-0.54). No sufficient evidence from the studies indicated that $\mathrm{GH}$ promoted the progression of intracranial tumors [14, 16, 25]. Ergun-Longmire et al. performed a retrospective study with 361 survivors treated with GH, and confirmed that these survivors were easier to trap in second neoplasms (RR 3.21) [3, 16]. Recent studies have reported no statistically significant increase in the risk of occurrence of the CNS subsequent neoplasms with GH exposure [33]. Equivocal conclusion on the issue was addressed by assessing the current resource. CNS tumors are a heterogeneous family of neoplasms that differ in tissue origins, degree of apoptosis, amplification, and invasive potential, especially during prognosis. Segregation of varied tumors and randomized controlled trials would be beneficial to confirm the potential relationship between $\mathrm{GH}$ treatment and second neoplasms.

Most of our studies included were retrospective in nature. Thus, some of the influencing factors were unavoidable. Additionally, years of follow-up were not equal or were too short. The optimum duration of recurrence/progression was probable beyond the follow-up period. The segregation of varied tumors with enough patients was required. Moreover, selection and publication bias in the 
Study

ID
$\%$

RR $(95 \% \mathrm{Cl}) \quad$ Weight

\begin{tabular}{|c|c|c|c|}
\hline Arslanian (1985) & & $1.11(0.37,3.35)$ & 0.47 \\
\hline Clayton (1987) & & $1.29(0.42,3.95)$ & 0.34 \\
\hline Ogilvy-Stuart (1992) & & $0.41(0.17,0.97)$ & 6.65 \\
\hline Swerdlow (2000) & - & $0.41(0.30,0.55)$ & 66.31 \\
\hline Packer1 (2001) & & $0.71(0.65,4.63)$ & 0.27 \\
\hline Packer2 (2001) & $=$ & $0.65(0.37,1.15)$ & 6.83 \\
\hline Sklar (2002) & - & $0.31(0.13,0.77)$ & 10.28 \\
\hline Rohrer (2010) & $\rightarrow$ & $0.62(0.37,1.06)$ & 8.85 \\
\hline Overall $(I-$ squared $=0.0 \%, p=0.680)$ & 0 & $0.44(0.34,0.54)$ & 100.00 \\
\hline $\begin{array}{c}1 \\
-4.63\end{array}$ & & $\$ 3$ & \\
\hline
\end{tabular}

Fig. 3 Forest plot of GHRT and tumor recurrence/progression in children

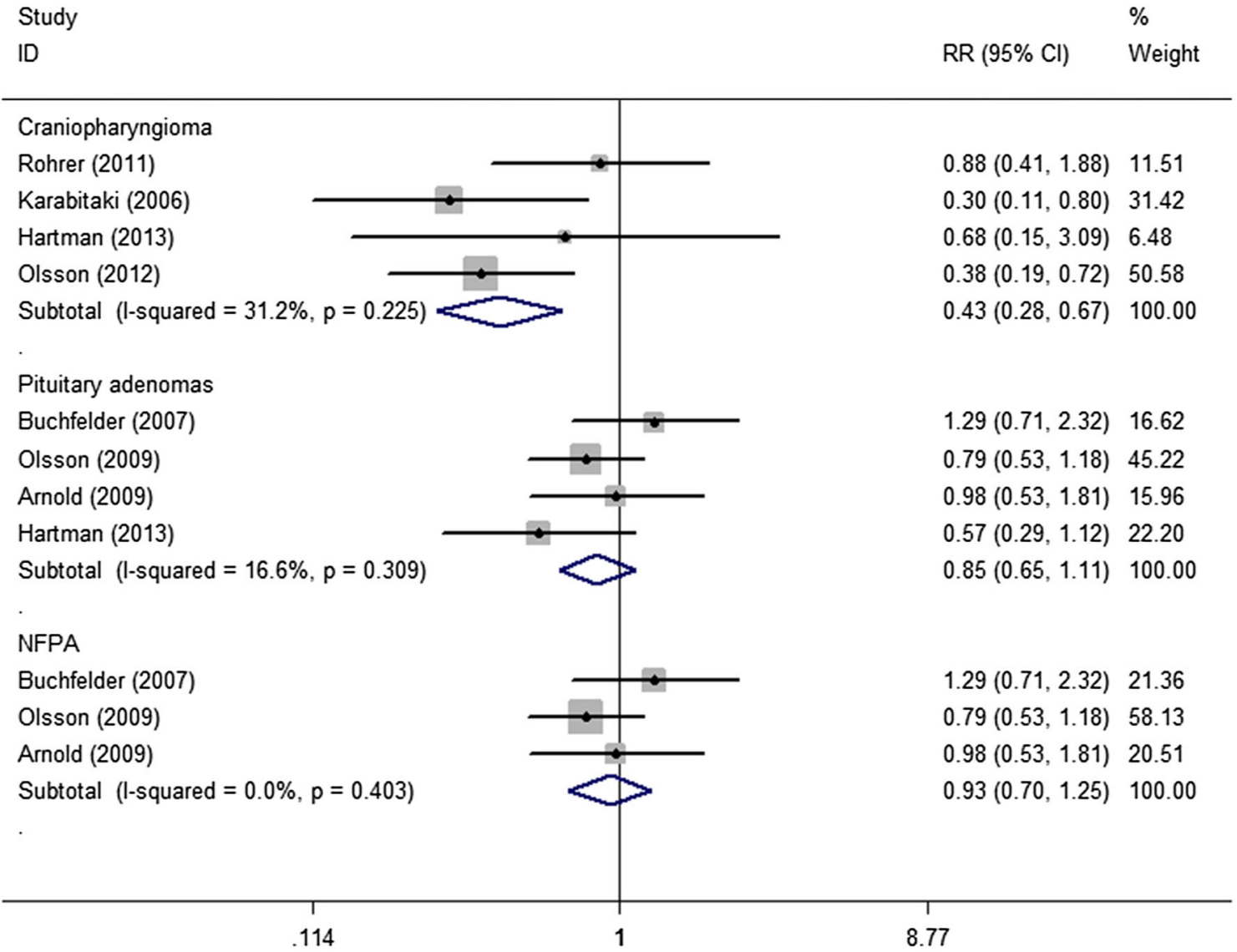

Fig. 4 Forest plot of GHRT and tumor recurrence/progression in craniopharyngioma, pituitary adenomas, and NFPA 


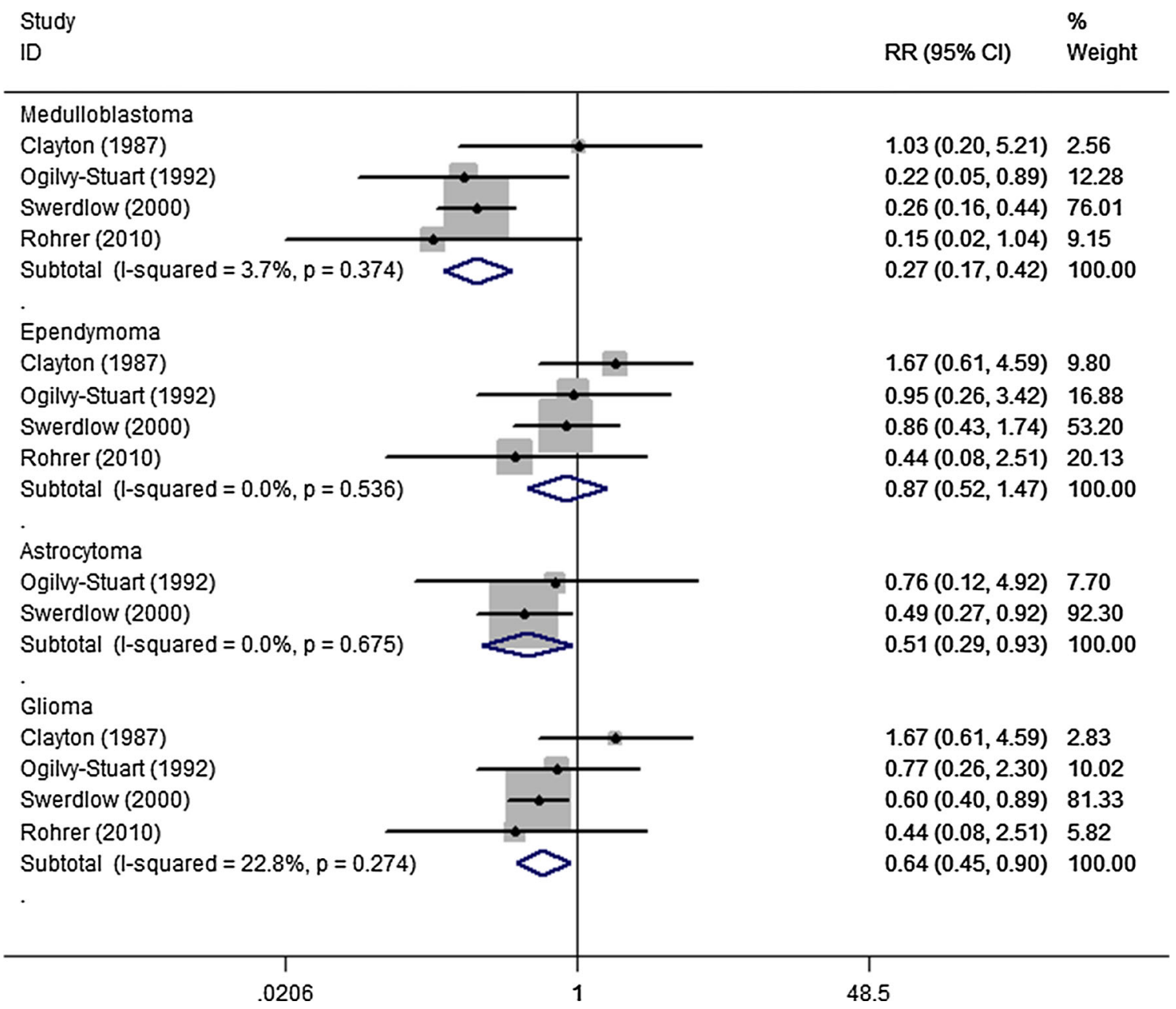

Fig. 5 Forest plot of GHRT and tumor recurrence/progression in medulloblastoma astrocytoma, and glioma

Fig. 6 Sensitivity analyses for GHRT and no-GHRT for intracranial tumors
Meta-analysis estimates, given named study is omitted I Lower Cl Limit | Upper Cl Limit

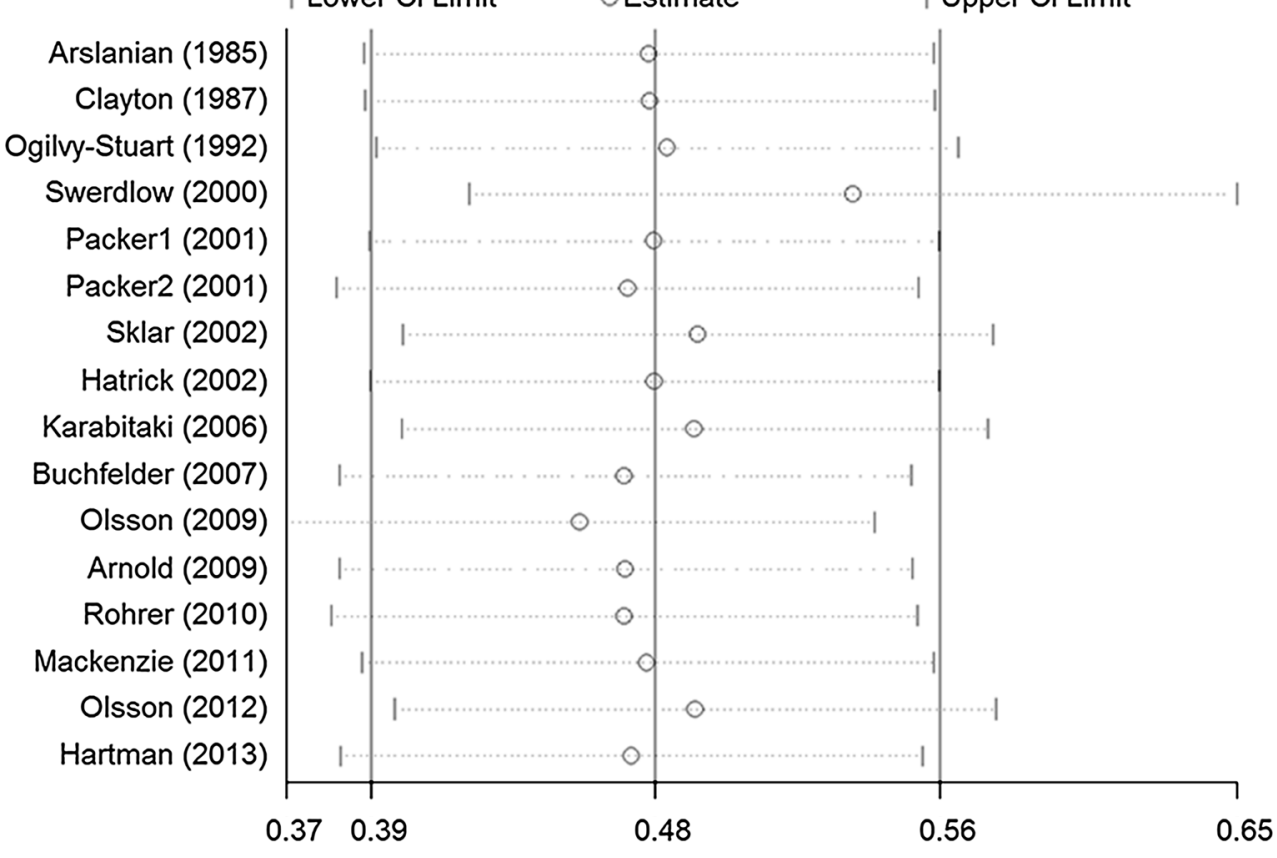


meta-analysis because of non-random samples and unpublished literatures.

Acknowledgments We would like to acknowledge the reviewers for their helpful comments on this paper.

Conflict of interest The authors have declared that no competing interests exist.

Open Access This article is distributed under the terms of the Creative Commons Attribution 4.0 International License (http:// creativecommons.org/licenses/by/4.0/), which permits unrestricted use, distribution, and reproduction in any medium, provided you give appropriate credit to the original author(s) and the source, provide a link to the Creative Commons license, and indicate if changes were made.

\section{References}

1. Cutter JL, Kurozumi K, Chiocca EA, Kaur B (2006) Gene therapeutics: the future of brain tumor therapy? Expert Rev Anticancer Ther 6(7):1053-1064

2. Moller N, Jorgensen JO (2009) Effects of growth hormone on glucose, lipid, and protein metabolism in human subjects. Endocr Rev 30(2):152-177

3. Ergun-Longmire B, Mertens AC, Mitby P, Qin J, Heller G, Shi W, Yasui Y, Robison LL, Sklar CA (2006) Growth hormone treatment and risk of second neoplasms in the childhood cancer survivor. J Clin Endocrinol Metab 91(9):3494-3498

4. Takala J, Ruokonen E, Webster NR, Nielsen MS, Zandstra DF, Vundelinckx G, Hinds CJ (1999) Increased mortality associated with growth hormone treatment in critically ill adults. N Engl J Med 341(11):785-792

5. Arnold JR, Arnold DF, Marland A, Karavitaki N, Wass JA (2009) GH replacement in patients with non-functioning pituitary adenoma (NFA) treated solely by surgery is not associated with increased risk of tumour recurrence. Clin Endocrinol (Oxf) 70(3):435-438

6. Mackenzie S, Craven T, Gattamaneni HR, Swindell R, Shalet SM, Brabant G (2011) Long-term safety of growth hormone replacement after CNS irradiation. J Clin Endocrinol Metab 96(9):2756-2761

7. Olsson DS, Buchfelder M, Wiendieck K, Kremenevskaja N, Bengtsson BA, Jakobsson KE, Jarfelt M, Johannsson G, Nilsson AG (2012) Tumour recurrence and enlargement in patients with craniopharyngioma with and without GH replacement therapy during more than 10 years of follow-up. Eur $\mathrm{J}$ Endocrinol 166(6):1061-1068

8. Stang A (2010) Critical evaluation of the Newcastle-Ottawa scale for the assessment of the quality of nonrandomized studies in meta-analyses. Eur J Epidemiol 25(9):603-605

9. Higgins JP, Thompson SG (2002) Quantifying heterogeneity in a meta-analysis. Stat Med 21(11):1539-1558

10. Higgins JP, Thompson SG, Deeks JJ, Altman DG (2003) Measuring inconsistency in meta-analyses. BMJ 327(7414):557-560

11. Zintzaras E, Ioannidis JP (2005) Heterogeneity testing in metaanalysis of genome searches. Genet Epidemiol 28(2):123-137

12. Egger M, Davey Smith G, Schneider M, Minder C (1997) Bias in meta-analysis detected by a simple, graphical test. BMJ 315(7109):629-634

13. Begg CB, Mazumdar M (1994) Operating characteristics of a rank correlation test for publication bias. Biometrics 50(4):1088-1101
14. Swerdlow AJ, Reddingius RE, Higgins CD, Spoudeas HA, Phipps K, Qiao Z, Ryder WD, Brada M, Hayward RD, Brook CG, Hindmarsh PC, Shalet SM (2000) Growth hormone treatment of children with brain tumors and risk of tumor recurrence. J Clin Endocrinol Metab 85(12):4444-4449

15. Packer RJ, Boyett JM, Janss AJ, Stavrou T, Kun L, Wisoff J, Russo C, Geyer R, Phillips P, Kieran M, Greenberg M, Goldman S, Hyder D, Heideman R, Jones-Wallace D, August GP, Smith SH, Moshang T (2001) Growth hormone replacement therapy in children with medulloblastoma: use and effect on tumor control. J Clin Oncol 19(2):480-487

16. Sklar CA, Mertens AC, Mitby P, Occhiogrosso G, Qin J, Heller G, Yasui Y, Robison LL (2002) Risk of disease recurrence and second neoplasms in survivors of childhood cancer treated with growth hormone: a report from the Childhood Cancer Survivor Study. J Clin Endocrinol Metab 87(7):3136-3141

17. Hatrick AG, Boghalo P, Bingham JB, Ayres AB, Sonksen PH, Russell-Jones DL (2002) Does GH replacement therapy in adult $\mathrm{GH}$-deficient patients result in recurrence or increase in size of pituitary tumours? Eur J Endocrinol 146(6):807-811

18. Karavitaki N, Warner JT, Marland A, Shine B, Ryan F, Arnold J, Turner HE, Wass JA (2006) GH replacement does not increase the risk of recurrence in patients with craniopharyngioma. Clin Endocrinol (Oxf) 64(5):556-560

19. Buchfelder M, Kann PH, Wuster C, Tuschy U, Saller B, Brabant G, Kleindienst A, Nomikos P (2007) Influence of GH substitution therapy in deficient adults on the recurrence rate of hormonally inactive pituitary adenomas: a case control study. Eur J Endocrinol 157(2):149-156

20. Olsson DS, Buchfelder M, Schlaffer S, Bengtsson BA, Jakobsson KE, Johannsson G, Nilsson AG (2009) Comparing progression of non-functioning pituitary adenomas in hypopituitarism patients with and without long-term GH replacement therapy. Eur J Endocrinol 161(5):663-669

21. Rohrer TR, Langer T, Grabenbauer GG, Buchfelder M, Glowatzki M, Dorr HG (2010) Growth hormone therapy and the risk of tumor recurrence after brain tumor treatment in children. J Pediatr Endocrinol Metab 23(9):935-942

22. Hartman ML, Xu R, Crowe BJ, Robison LL, Erfurth EM, Kleinberg DL, Zimmermann AG, Woodmansee WW, Cutler GB Jr, Chipman JJ, Melmed S (2013) Prospective safety surveillance of GH-deficient adults: comparison of GH-treated vs untreated patients. J Clin Endocrinol Metab 98(3):980-988

23. Arslanian SA, Becker DJ, Lee PA (1985) Growth hormone therapy and tumor recurrence. Findings in children with brain neoplasms and hypopituitarism. Am J Dis Child 139(4):347-350

24. Clayton PE, Shalet SM, Gattamaneni HR, Price DA (1987) Does growth hormone cause relapse of brain tumours? Lancet 1(8535):711-713

25. Ogilvy-Stuart AL, Ryder WD, Gattamaneni HR, Clayton PE, Shalet SM (1992) Growth hormone and tumour recurrence. BMJ 304(6842):1601-1605

26. Karavitaki N, Warner JT, Marland A, Shine B, Ryan F, Arnold J, Turner HE, Wass JAH (2006) GH replacement does not increase the risk of recurrence in patients with craniopharyngioma. Clin Endocrinol 64(5):556-560

27. Yao NH, Yao DF, Dong ZZ, Yan XD, Chen J, Yao M, Wang L, Yan MJ (2013) Effects of inhibited IGF-IR expression on proliferation and apoptosis of human hepatocellular carcinoma cell lines. Zhonghua Gan Zang Bing Za Zhi 21(5):376-380

28. Pekic S, Popovic V (2013) GH therapy and cancer risk in hypopituitarism: what we know from human studies. Eur J Endocrinol 169(5):R89-R97

29. Renehan AG, Zwahlen M, Minder C, O’Dwyer ST, Shalet SM, Egger M (2004) Insulin-like growth factor (IGF)-I, IGF binding 
protein-3, and cancer risk: systematic review and meta-regression analysis. Lancet 363(9418):1346-1353

30. Berg CA, Pokrajac A, Bidlingmaier M, Strasburger CJ, Shalet SM, Trainer PJ (2009) Use of a GH receptor antagonist (GHRA) to explore the relationship between GH and IGF-I in adults with severe GH deficiency (GHD). Clin Endocrinol (Oxf) 70(3):439-445

31. Chan JM, Stampfer MJ, Giovannucci E, Gann PH, Ma J, Wilkinson P, Hennekens CH, Pollak M (1998) Plasma insulinlike growth factor-I and prostate cancer risk: a prospective study. Science 279(5350):563-566
32. Hankinson SE, Willett WC, Colditz GA, Hunter DJ, Michaud DS, Deroo B, Rosner B, Speizer FE, Pollak M (1998) Circulating concentrations of insulin-like growth factor-I and risk of breast cancer. Lancet 351(9113):1393-1396

33. Patterson BC, Chen Y, Sklar CA, Neglia J, Yasui Y, Mertens A, Armstrong GT, Meadows A, Stovall M, Robison LL, Meacham LR (2014) Growth hormone exposure as a risk factor for the development of subsequent neoplasms of the central nervous system: a report from the childhood cancer survivor study. J Clin Endocrinol Metab 99(6):2030-2037 